\title{
Meiofauna and sedimentary organic matter off Central Chile: response to changes caused by the 1997-1998 El Niño
}

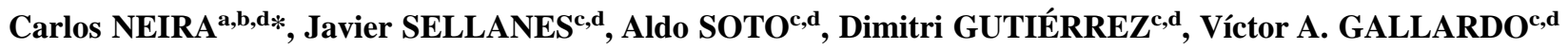 \\ ${ }^{a}$ Institute for Chemistry and Biology of the Marine Environment (ICBM), Carl-von-Ossietzky-Universität \\ Oldenburg, Postfach 2503, 26111 Oldenburg, Germany \\ b Present address: Marine Life Research Group, Scripps Institution of Oceanography, La Jolla, CA 92093-0218, \\ USA \\ c Departamento de Oceanografía, Universidad de Concepción, Casilla 160-C, Concepción, Chile \\ ${ }^{\mathrm{d}}$ FONDAP-HUMBOLDT, Programme CONICYT, Canada 308, Providencia-Santiago, Chile
}

Received 30 October 2000; revised 12 February 2001; accepted 20 February 2001

\begin{abstract}
Quantitative surveys of metazoan meiofauna were carried out in an upwelling region off Central Chile ( $\left.36^{\circ} \mathrm{S}\right)$. During May 1997 and May 1998, coinciding with the onset and end of El Niño, five benthic stations (respectively 27, 34, 64,88 , and $120 \mathrm{~m}$ depth), from the middle of Concepción Bay to the edge of the adjacent continental shelf, were sampled. The sedimentary organic matter biopolymeric fraction (proteins, carbohydrates and lipids) and chloroplastic pigments were also assessed. Total meiofauna abundance and biomass increased significantly between sampling dates at the mid-bay and inner shelf sites, from $1474 \pm 354$ to $5035 \pm 291$ individuals $10 \mathrm{~cm}^{-2}$ and from $2618 \pm 332$ to $5241 \pm 903$ individuals $10 \mathrm{~cm}^{-2}$, respectively. The relative importance of copepods in the top $2 \mathrm{~cm}$ increased at all sites (except in the bay mouth). During May 1998, meiofauna, especially nematodes, penetrated deeper in the bay, as well as in the inner and middle shelf sediments. Changes observed in meiobenthos structure among sites and periods were attributed to the higher oxygenation of bottom waters during the summer of 1998 (i.e. El Niño conditions). This was most evident at sites such as the mid bay, where during non-El Niño years, oxygen-deficient conditions prevail. A decrease of organic matter quantity and quality, related to low primary productivity conditions in 1998 (El Niño), apparently caused few changes in meiofauna structure. A positive correlation between Thioploca and the meiofauna biomass was observed in May 1997, whereas in May 1998 no relationship was found. () 2001 Ifremer/CNRS/IRD/Éditions scientifiques et médicales Elsevier SAS
\end{abstract}

Résumé - Méiofaune et matière organique du sédiment sur les côtes du Chili central : réponses aux changements causés par «El Niño », 1997-1998. Des mesures quantitatives de la méiofaune ont été réalisées dans une région côtière du Chili central $\left(36^{\circ} \mathrm{S}\right)$. Pendant les périodes de mai 1997 et de mai 1998, qui coïncident avec l'apparition et la disparition d'El Niño, cinq stations (27, 34, 64, 88, $120 \mathrm{~m}$ de profondeur), comprises entre le milieu de la baie de Concepción et le bord du plateau continental, ont été examinées. La fraction de matières organiques sédimentaires (protéines, hydrates de carbone et lipides) ainsi que les pigments chloroplastiques ont été déterminés. L'abondance de la méiofaune et sa biomasse augmentent significativement : dans le milieu de la baie, de $1474 \pm 354$ à $5035 \pm 291$ individus pour $10 \mathrm{~cm}^{-2}$, dans les sites intérieurs du plateau, de $2618 \pm 332$ à $5241 \pm 903$ individus pour $10 \mathrm{~cm}^{-2}$. L'importance relative des copépodes dans les $2 \mathrm{~cm}$ supérieurs augmente dans presque tous les sites, à l'exception de l'entrée de la baie. En mai 1998, la méiofaune, en particulier les nématodes, pénètre plus profondément dans les sédiments de la baie que dans ceux de l'intérieur et du centre du plateau. Les changements de la structure du méiobenthos, sont attribués à la haute oxygénation de l'été 1998 (El Niño). Ceci est plus évident dans les sites où, pendant les années sans El Niño, des conditions de déficience en oxygène ont prévalu, c'est-à-dire dans le milieu de la baie. La décroissance de la qualité et de la quantité

*Correspondence and reprints: fax: +18588220562.

E-mail address: cneira@ coast.ucsd.edu (C. NEIRA).

(C) 2001 Ifremer/CNRS/IRD/Éditions scientifiques et médicales Elsevier SAS. Tous droits réservés

S0399178401011495/FLA 
de la matière organique révèle que les conditions de basse productivité en 1998 (El Niño) jouent un rôle mineur dans les changements de la structure de la méiofaune. Une correlation positive a été observée entre Thioploca et la biomasse de la méiofaune en mai 1997, tandis qu'aucune n'a été trouvée en mai 1998. (C 2001 Ifremer/CNRS/IRD/Éditions scientifiques et médicales Elsevier SAS

\section{Central Chile / El Niño / meiofauna / organic matter / Thioploca}

\section{Chili central / El Niño / méiofaune / matière organique / Thioploca}

\section{INTRODUCTION}

The coastal waters off Central Chile are an important area of seasonal and episodic wind-driving upwelling, and exhibit very complex hydrography (Ahmmada_et_al 1983). Primary productivity values up to $9.6 \mathrm{gC} \mathrm{m}^{-2}$ day $^{-1}$ (Gallardo, 1977) have been reported. A large fraction of this primary production (ca. 25-40\%) settles on the bottom Bernal et al__ 1989). Hence, sediments underlying this system tend to have higher accumulation rates and sediment organic carbon contents than other coastal marine sediments.

High remineralization rates at the sediment-water interface promote anoxic conditions in sediments Henrich and Earrington, 1984) Daily, weekly, monthly, and interannual changes in upwelling intensity (e.g. El Niño-Southern Oscillation related events) could lead to changes in bottom water oxygen levels, and in the quantity and quality of organic matter reaching the sediment. Usually an oxygen minimum layer $\left(<0.5 \mathrm{~mL} \mathrm{~L}^{-1}\right)$ associated with the Equatorial SubSurface Waters (ESSW), is present at depths from 50 to $250 \mathrm{~m}$ in the Bay of Concepción and in part of the adjacent shelf $\left(36^{\circ} \mathrm{S}\right.$, foure -1$)$. This feature appears in early spring and disappears at the beginning of autumn. During the rest of the year, water column oxygen conditions approach saturation.

Another characteristic of this area during non-El Niño periods, is the seasonal development of a peculiar community mostly composed of filamentous, gliding bacteria Thioploca spp. Gallardo, 1977; Schulz et al, 2000) Thioploca is capable of effectively oxidizing up to $35 \%$ of the sulphide formed in the sediments, using nitrate as an electron acceptor Fossing et al. 1995: Ferdelman ed bl. 1997). Hence Thioploca mats may enhance conditions for aerobic organisms by removing toxic sulphide in subsurface sediment layers Gallardo et al. 1996a Moreover, the organic-rich matrix of sediment, contain- ing bundles of Thioploca trichomes enclosed in gelatinous sheaths, forms a fluffy structure with cavities and small channels (Huettel et al. 1996). Thioploca mats may therefore constitute a suitable microhabitat for meiofauna. Studies in the area off Central Chile have been focused mainly on macrofauna communities GalLardo, 1985. Gallardo et al, 1995; Gallardo et al, 1996h; Gutiérrez et al, 2000). The meiobenthos, in contrast, is poorly known, particularly regarding its relationships with other faunal components and with environmental factors such as oxygen and food availability.

Two hypotheses were tested, using El Niño conditions as a natural experiment that allowed the examination of the same sites under different environmental conditions: 1) El Niño events will change the organic matter composition and hence the quality of food sources available to benthic consumers, and 2) meiofaunal community structure is affected by changes in the composition of sedimentary organic matter and alterations of physicochemical factors such as bottom water oxygen concentration that are associated with the 1997-1998 El Niño. Such effects should be most evident in sediment where oxygen-deficient conditions prevail during non-El Niño years. Another aim of this study was to test the assumption that Thioploca presence might favour the establishment of meiofauna in suboxic bottoms. Characteristics and El Niño effects on filamentous bacteria and macrofaunal communities are reported elsewhere Gutiérrez et al.2000)

\section{MATERIALS AND METHODS}

\subsection{Sampling}

Five stations were sampled along an east-northwest transect off Central Chile during two periods: May 1997 and May 1998. These are the same sites sampled during 
Figure 1. Location of study off Central Chile indicating sites sampled in May 1997 and May 1998: mid-bay site (Sta. 4), bay mouth site (Sta. 7), innershelf site (Sta. 14), midshelf site (Sta. 18), outershelf site (Sta. 26).

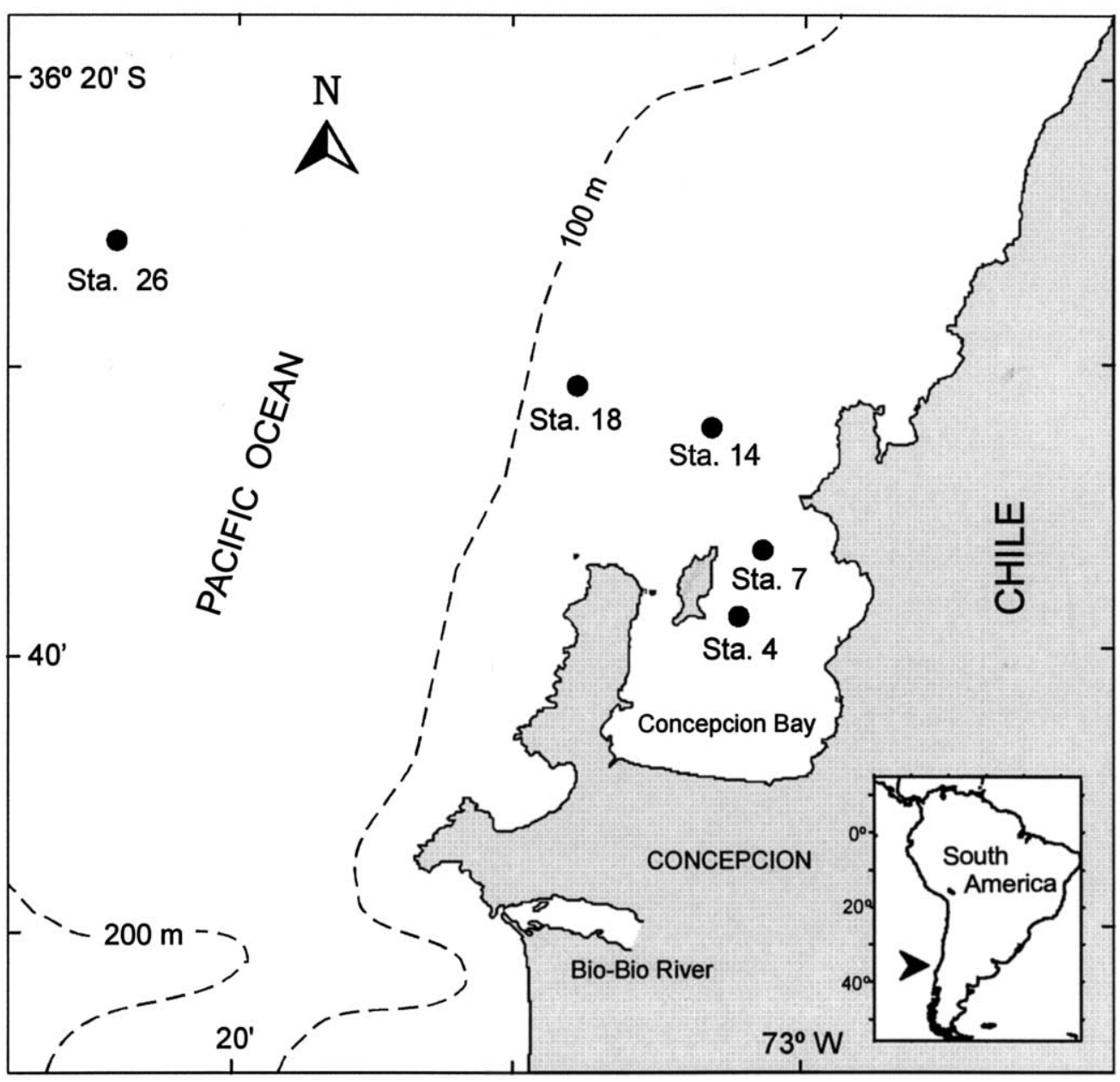

the Thioploca-Chile-94 Expedition (Fossing et al. 1995 and are characterized by silty sediments $(95 \%$ silt; Gutiérrez et al_2000) The transect started in the middle of the eutrophic Bay of Concepción $(27 \mathrm{~m})$ and ended at the shelf break $(120 \mathrm{~m})$. The stations were categorized as: mid-bay (station 4, $27 \mathrm{~m}$ ), bay mouth (station 7, $34 \mathrm{~m}$ ), inner shelf (station 14, $64 \mathrm{~m}$ ), middle shelf (station 18, $88 \mathrm{~m}$ ), and outer shelf (station 26, $120 \mathrm{~m}$ ) (Goure $)$. The sampling coincided with the onset and end of the 1997-1998 El Niño, one of the strongest of the century (McPhaden, 1999) Sediment samples were taken from aboard the RV Kay Kay (University of Concepción) with a Rumohr corer and a minimultiple corer Barnett et al. 1984). Only undisturbed cores with clear overlying water were used. Locations and bottom water physico-chemical parameters of the studied sites are shown in table

\subsection{Meiofauna and Thioploca analysis}

For meiofauna, three replicates (each from different Rumohr/MUC drops) were taken by gently inserting a perspex tube of $3.6 \mathrm{~cm}$ inner diameter into the original cores. Sediment from the subcores was sliced into four vertical sections $(0-2 \mathrm{~cm}$, including some overlying water; $2-5 ; 5-10$, and $10-15 \mathrm{~cm}$ ) and treated with a $6 \%$ solution of magnesium chloride. After $20 \mathrm{~min}, 10 \%$ formalin containing rose Bengal $\left(0.2 \mathrm{~g} \mathrm{~L}^{-1}\right)$ was added for fixation and staining. Three replicates were taken to estimate Thioploca biomass using the biovolume method (Schulz et al. 1996). Meiofaunal taxa, defined here as metazoans that pass through a $0.5 \mathrm{~mm}$ mesh sieve and are retained on a $0.063 \mathrm{~mm}$ sieve (Giere, 1993) were sieved following the resuspension-decantation methodology 
Table I. Location of the studied stations and bottom water physico-chemical parameters.

\begin{tabular}{|c|c|c|c|c|c|c|c|}
\hline Station & Depth (m) & Latitude (S) & Longitude (W) & Sampling date & $T\left({ }^{\circ} \mathrm{C}\right)$ & Salinity & $B W D O\left(\mathrm{~mL} \mathrm{~L}^{-1}\right)$ \\
\hline \multirow[t]{2}{*}{4} & 27 & $36^{\circ} 38.7^{\prime}$ & $73^{\circ} 02.2^{\prime}$ & May 97 & 14.15 & 34.38 & 3.62 \\
\hline & & & & May 98 & 14.40 & 33.77 & 4.06 \\
\hline \multirow[t]{2}{*}{7} & 34 & $36^{\circ} 36.5^{\prime}$ & $73^{\circ} 00.6^{\prime}$ & May 97 & 14.00 & 34.35 & 5.20 \\
\hline & & & & May 98 & 14.60 & 33.70 & 5.00 \\
\hline \multirow[t]{2}{*}{14} & 64 & $36^{\circ} 32.1^{\prime}$ & $73^{\circ} 03.1^{\prime}$ & May 97 & 13.80 & 34.36 & 5.05 \\
\hline & & & & May 98 & 12.65 & 34.32 & 2.65 \\
\hline \multirow[t]{2}{*}{18} & 88 & $36^{\circ} 30.8^{\prime}$ & $73^{\circ} 07.7^{\prime}$ & May 97 & 11.64 & 34.79 & 0.28 \\
\hline & & & & May 98 & 11.70 & 34.40 & 1.11 \\
\hline \multirow[t]{2}{*}{26} & 120 & $36^{\circ} 25.9^{\prime}$ & $73^{\circ} 23.4^{\prime}$ & May 97 & 11.70 & 34.84 & 0.19 \\
\hline & & & & May 98 & 11.40 & 34.48 & 1.39 \\
\hline
\end{tabular}

$B W D O$ : bottom water dissolved oxygen.

Wieser 1960 with a few modifications (Neira and Rackemann, 1996). All meiofaunal animals were sorted into major taxa, counted under a stereo dissecting microscope, and preserved for later biomass determination. The body volume of nematodes was derived from measurements of body length and width using the Andrassy formula $V=L W^{2} / 16 \times 10^{5}$ (Andrassy_ 1956) where $V$ is the volume in nanolitres, $L$ the length and $W$ the maximum width ( $L$ and $W$ expressed in micrometres). For other taxa, the body volume was estimated as described by Feller and Warwick (1988). Carbon values were taken to be $12.4 \%$ of the wet weight (Jensen, 1984) which in turn was obtained from multiplying volume by specific gravity (assumed to be 1.13) (Wieser, 1960). Dry weight was assumed to be $25 \%$ of the wet weight.

\subsection{Sediment parameters}

Sediment redox potential $(E h)$ was measured at intervals of $1 \mathrm{~cm}$ using a platinum standard combination electrode with a calomel internal reference. Water content and porosity were determined at $1 \mathrm{~cm}$ intervals. Additional cores were subsampled for chlorophyll $a$ (Chl $a$ ) and phaeopigments, total organic carbon and nitrogen, and the main biochemical components of organic matter: lipids, carbohydrates, and proteins. Cores were sliced at depth intervals of $0-1,1-3,3-5,5-7,7-9,9-11,11-13$, $13-15 \mathrm{~cm}$ and were kept deep-frozen until later analysis. Two additional cores were subsampled for dissolved sulphide. Pore water was extracted under a $\mathrm{N}_{2}$ atmosphere with a pneumatic squeezer at 1 and $2 \mathrm{~cm}$ sections down to $15 \mathrm{~cm}$ sediment. Porewater sulphide was determined colorimetrically at $670 \mathrm{~nm}$ using the methylene blue technique (Cline, 1969).
Total organic carbon (TOC) and nitrogen $(T N)$ were determined (after acidification with $1 \mathrm{~N} \mathrm{HCl}$ to remove carbonates) using a Heraeus-CHN elemental analyzer. Chl $a$ and phaeopigments were analyzed spectrophotometrically according to Stalet_al_(1984) Carbohydrate content in sediment was quantified spectrophotometrically as described by Taylor and Paterson (1998), with glucose as a reference. Lipid content was determined in methanol-chloroform extracts following the protocol for marine sediments as described by Greiser and Faubel (1988). The dry residue was weighed after complete evaporation of the solvent. Proteins were determined photometrically by the Coomasie blue reaction after incubation for $2 \mathrm{~h}$ at $60^{\circ} \mathrm{C}$ with $0.5 \mathrm{~N} \mathrm{NaOH}$ Boetius et al. 1996) and further centrifugation, and expressed as albumin equivalents. The biopolymeric fraction of sedimentary organic carbon (hereafter $C-L O M$ ) was defined as the sum of the protein, carbohydrate and lipid carbon Eabiano and Danovaro, 1994: Fabiano et al. 1995. Lipid, carbohydrate and protein were converted into carbon equivalents using conversion factors of 0.70 , 0.40 , and 0.49 , respectively Eabiano et al. 1995. The labile organic carbon $(C-L O M)$ contribution to the TOC was assumed to represent the nutritional value (quality) of organic matter and was calculated as $[C-L O M / T O C] \times 100$ [Eabiano et al._ 1993)

\subsection{Data analysis}

Factorial analysis of variance (ANOVA) was used to detect differences in meiofauna abundance and biomass between sites and sampling dates. When necessary, square root transformed data were used in order to remove heteroscedasticity and/or to correct residuals. 
Table II. Sediment and overlying water redox potential and sulphide concentration measured in May 1997 and May 1998 at the study sites.

\begin{tabular}{|c|c|c|c|c|c|c|c|c|c|c|}
\hline \multirow[b]{2}{*}{ Depth } & \multicolumn{2}{|c|}{ Station 4} & \multicolumn{2}{|c|}{ Station 7} & \multicolumn{2}{|c|}{ Station 14} & \multicolumn{2}{|c|}{ Station 18} & \multicolumn{2}{|c|}{ Station 26} \\
\hline & $E h$ & $\mathrm{H}_{2} \mathrm{~S}$ & $E h$ & $\mathrm{H}_{2} \mathrm{~S}$ & $E h$ & $\mathrm{H}_{2} \mathrm{~S}$ & $E h$ & $\mathrm{H}_{2} \mathrm{~S}$ & $E h$ & $\mathrm{H}_{2} \mathrm{~S}$ \\
\hline \multicolumn{11}{|c|}{ May 1997} \\
\hline bw & 215 & 12.58 & 468 & 10.5 & 450 & 8.83 & 437 & 3.79 & nd & 6.75 \\
\hline $0-1$ & -23 & 96.15 & 189 & 14.25 & 251 & 7.13 & 302 & 4.63 & nd & 11.33 \\
\hline $1-3$ & -56 & 803.00 & 157 & 14.67 & 200 & 9.67 & 194 & 2.13 & nd & 5.08 \\
\hline $3-5$ & -80 & 1653.46 & 137 & 18.00 & 154 & 10.5 & 168 & 2.54 & nd & 8.00 \\
\hline $5-7$ & -166 & 1645.00 & 82 & 13.83 & 104 & 12.58 & 121 & 13.00 & nd & 7.17 \\
\hline $7-9$ & -176 & 1938.08 & 28 & 14.67 & -2 & 13.79 & 93 & 7.96 & nd & 5.08 \\
\hline $9-11$ & -179 & 1671.54 & -12 & 20.92 & -48 & 11.33 & 54 & 42.54 & nd & 9.67 \\
\hline $11-13$ & -183 & 1797.69 & -47 & 28.83 & -89 & 3.38 & -4 & 64.21 & nd & 9.67 \\
\hline $13-15$ & -186 & 1454.62 & -106 & 12.17 & -106 & 4.21 & -40 & 89.63 & nd & 10.08 \\
\hline \multicolumn{11}{|c|}{ May 1998} \\
\hline bw & 239 & 26.36 & 374 & 24.16 & 388 & 22.36 & 389 & 28.36 & 485 & 23.96 \\
\hline $0-1$ & 67 & 27.16 & 149 & 24.36 & 168 & 21.56 & 86 & 20.36 & 178 & 21.56 \\
\hline $1-3$ & 3 & 36.66 & 91 & 21.56 & 76 & 26.16 & 52 & 23.16 & 158 & 20.76 \\
\hline $3-5$ & -126 & 24.56 & 56 & 40.76 & 32 & 20.36 & 32 & 23.36 & 107 & 21.76 \\
\hline $5-7$ & -175 & 39.56 & -2 & 22.76 & -33 & 21.56 & 13 & 23.16 & 67 & 22.36 \\
\hline $7-9$ & -180 & 60.36 & -56 & 22.56 & -76 & 21.76 & -34 & 30.36 & 52 & 29.36 \\
\hline $9-11$ & -184 & 117.56 & -104 & 21.96 & -106 & 21.56 & -85 & 27.56 & 32 & 23.16 \\
\hline $11-13$ & -190 & 178.16 & -127 & 28.16 & -129 & 20.36 & -103 & 21.16 & 1 & 22.36 \\
\hline $13-15$ & -194 & 180.16 & -147 & 23.96 & -145 & 21.96 & -119 & 28.76 & -26 & 22.76 \\
\hline
\end{tabular}

Redox potential $(E h)$ in millivolts, sulphide $\left(\mathrm{H}_{2} S\right)$ concentration in micromolar, depth in centimetres; bw: bottom water; nd: not determined.

The Mann-Whitney U-test was used to contrast abundances and biomasses and environmental factors, between both stations and sampling dates when ANOVA indicated significative differences. Spearman rank correlations were used to test for relationships between meiofaunal abundances and environmental variables. Pearson product-moment correlations were used to test for relationships between Thioploca and meiofaunal biomass (both square root transformed). All tests were performed using the Systat 8.0 software package (Wilkinson et al 1992) and Statistica 5.1 (StatSoft Inc.).

\section{RESULTS}

\subsection{Sediment physico-chemistry}

Porosity ranged from $57 \%$ to $97 \%$, and water content ranged from $32 \%$ to $86 \%$ in May 1997. In May 1998, they ranged from $76 \%$ and $91 \%$, and $61 \%$ to $78 \%$, respectively. Highest values of porosity and water content always occurred at the mid-bay site (station 4) where the top $2 \mathrm{~cm}$ were flocculent and loose (fluffy). At station 4 , the whole sediment column was black, oily, and smelled of sulphide in May 1997. However, in May 1998 a brown uppermost layer was present; $E h$ increased from $-23 \mathrm{mV}$ in May 1997 to $+67 \mathrm{mV}$ in May 1998. At the shelf sites, the thickness of the oxidized layer $(E h>0)$ fluctuated between $5-12 \mathrm{~cm}$; the outer shelf sediments were the most oxidized (table I t ). Marked differences in sulphide concentration were observed between the mid-bay and the shelf sites during both 1997 and 1998. In the mid-bay site (station 4), a significant reduction in sulphide was recorded (from 1382.4 to $83.0 \mu \mathrm{M}$, mean $0-15 \mathrm{~cm}$; (Utest, $P<0.01$ ), whereas an increase was observed in the bay mouth (station 7) and in the inner (station 14) and outer shelf (station 26) sites (U-test, $P<0.01$ ). In the middle shelf site (station 18) a slight decrease was observed. Mean sulphide concentrations in the shelf were low $(<30 \mu \mathrm{M})$ during both sampling periods.

\subsection{Photosynthetic pigments}

Sediments-bound pigments were mainly phaeopigments. Chl $a$ concentration ranged from 1.62 to $20.32 \mu \mathrm{g} \mathrm{g}^{-1}$ dry weight (May 1997), and from 0.86 to 5.72 (May 1998) in 


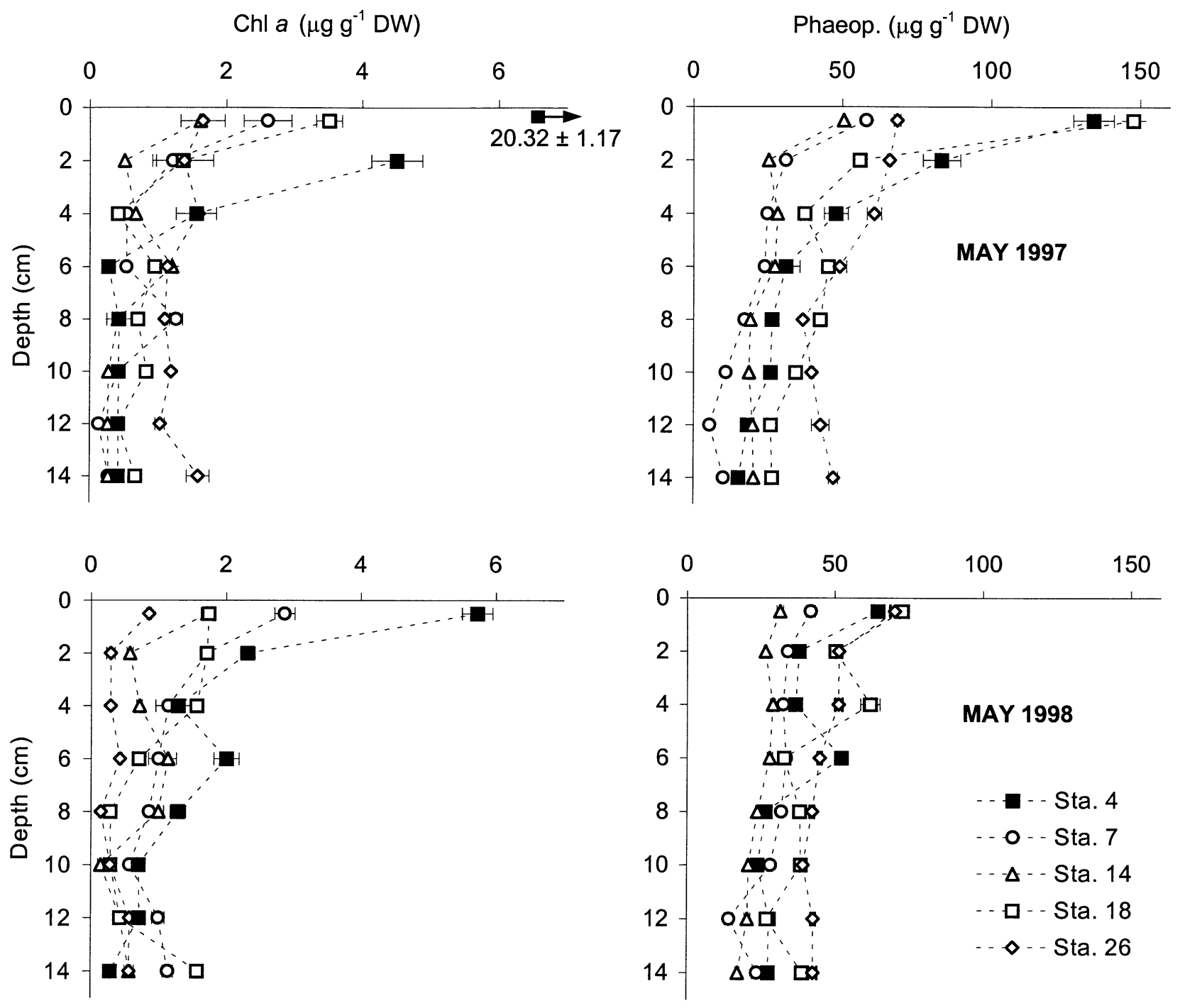

Figure 2. Chlorophyll $a$ and phaeopigment profiles in sediment at the study sites, in May 1997 and in May 1998. Note the high concentration of Chl $a$ in the first centimetre in May 1997. Values are mean \pm SE.

the top $1 \mathrm{~cm}$ (Goure 2). Chloroplastic pigment equivalents $(C P E)$, representing the sum of $\mathrm{Chl} a$ and phaeopigments (Pfannkuche, 1985) ranged from 8 to $154.6 \mu \mathrm{g} \mathrm{g}^{-1}$ dry weight and from 19.47 to $70.15 \mu \mathrm{g} \mathrm{g}^{-1}$ dry weight, in May 1997 and May 1998, respectively. Chl $a$ always comprised less than $10 \%$ of the CPE, except at the mid-bay site in May 1997, when Chl $a$ accounted for $13.1 \%$ of the $C P E$. In general, there was a steep decrease in pigment concentrations down to $3-4 \mathrm{~cm}$. Chl $a$ was measured down to $15 \mathrm{~cm}$ depth at all stations, although in negligible concentrations.

\subsection{Elemental and biochemical composition of organic matter}

Sediment total organic carbon $(0-1 \mathrm{~cm})$ ranged from 29.9 to $50.0 \mathrm{mgC} \mathrm{g}^{-1}$ dry weight in May 1997 , and 25.3 to $46.9 \mathrm{mgC} \mathrm{g}^{-1}$ dry weight in May 1998. Sediment organic nitrogen $(0-1 \mathrm{~cm})$ ranged from 3.8 to $8.2 \mathrm{mg} \mathrm{g}^{-1}$ dry weight, and from 2.9 to $6.5 \mathrm{mg} \mathrm{g}^{-1}$ dry weight during May 1997 and May 1998, respectively. The highest organic carbon concentration was found in May 1997 in 

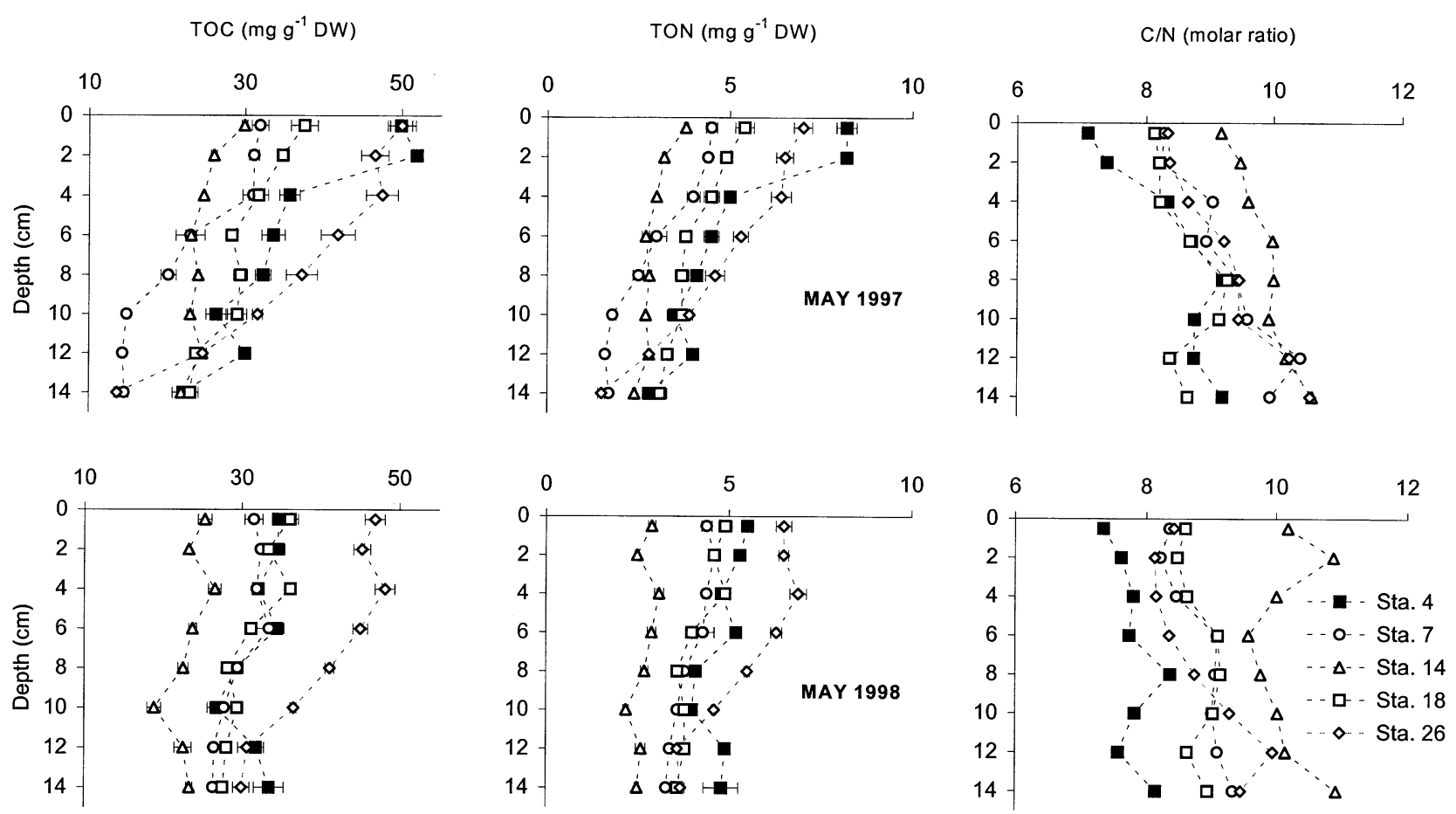

Figure 3. Profiles of total organic carbon (TOC), total organic nitrogen (TON) and C:N ratios in sediments of the sites studied during May 1997 and May 1998. Values are mean \pm SE.

the top $3 \mathrm{~cm}$ sediment layer of the mid-bay and outer shelf sites. The mid-bay sediment showed a clear reduction in TOC between years, whereas the decrease was moderate at the other sites. In general, organic carbon and nitrogen content decreased with depth in the sediment (figure 3). The $C: N$ (molar) ratio of the organic matter in the bottom sediments did not exhibit large fluctuations. The $C: N$ ratios increased downcore. A slight increase of the $C: N$ ratios between May 1997 and May 1998 was recorded in the top $1 \mathrm{~cm}$ at each station. The inner shelf site (station 14) exhibited the highest surface $C: N$ ratio in both periods.

In general, the three main biochemical components of the organic matter (carbohydrates: $\mathrm{CHO}$, proteins: $P R T$, and lipids: $L I P)$ declined with increasing depth in the sediment (Ggure 4). All sites exhibited a reduction in the content of biochemical compounds of surface sediments $(0-1 \mathrm{~cm})$ between 1997 and 1998 except for the bay mouth and inner shelf sites, where lipid and protein content, respectively, increased slightly $($ table $U$ C $)$. Similarly, the labile fraction $(C-L O M)$ of $T O C$ within the uppermost layer of sediment $(0-1 \mathrm{~cm})$ decreased notice- ably at the mid-bay, middle shelf and outer shelf sites. There was a negligible change at the bay mouth and inner shelf sites. The nutritional quality of the sediment organic matter for meiofauna is reflected in the proportion of specific labile compounds within the top $1 \mathrm{~cm}$ (table $ل$ Wh). Integrated mean values $(0-15 \mathrm{~cm}$ sediment $)$ of the specific biochemical components (in terms of carbon equivalents) of all sites revealed that between May 1997 and May $1998 \mathrm{C}$ - $\mathrm{CHO}$ diminished from $8.9 \%$ to $4.7 \%$, $C$-PRT from $10.4 \%$ to $3.0 \%$, and C-LIP from $9.9 \%$ to $8.3 \%$. Further the biopolymeric carbon fraction potentially available to benthic consumers decreased from $37 \%$ to $27 \%$ of the TOC.

\subsection{Meiofauna}

Meiofaunal abundance ranged from $1318 \pm 345$ to $10796 \pm 2017$ individuals $10 \mathrm{~cm}^{-2}$ (mean \pm SE) in May 1997 and from $758 \pm 204$ to $8622 \pm 1353$ individuals $10 \mathrm{~cm}^{-2}$ in May 1998 (figure 5 d). Highest densities, comprised largely of nematodes (figure $5 b$ ), were always found at the bay mouth site and the lowest 

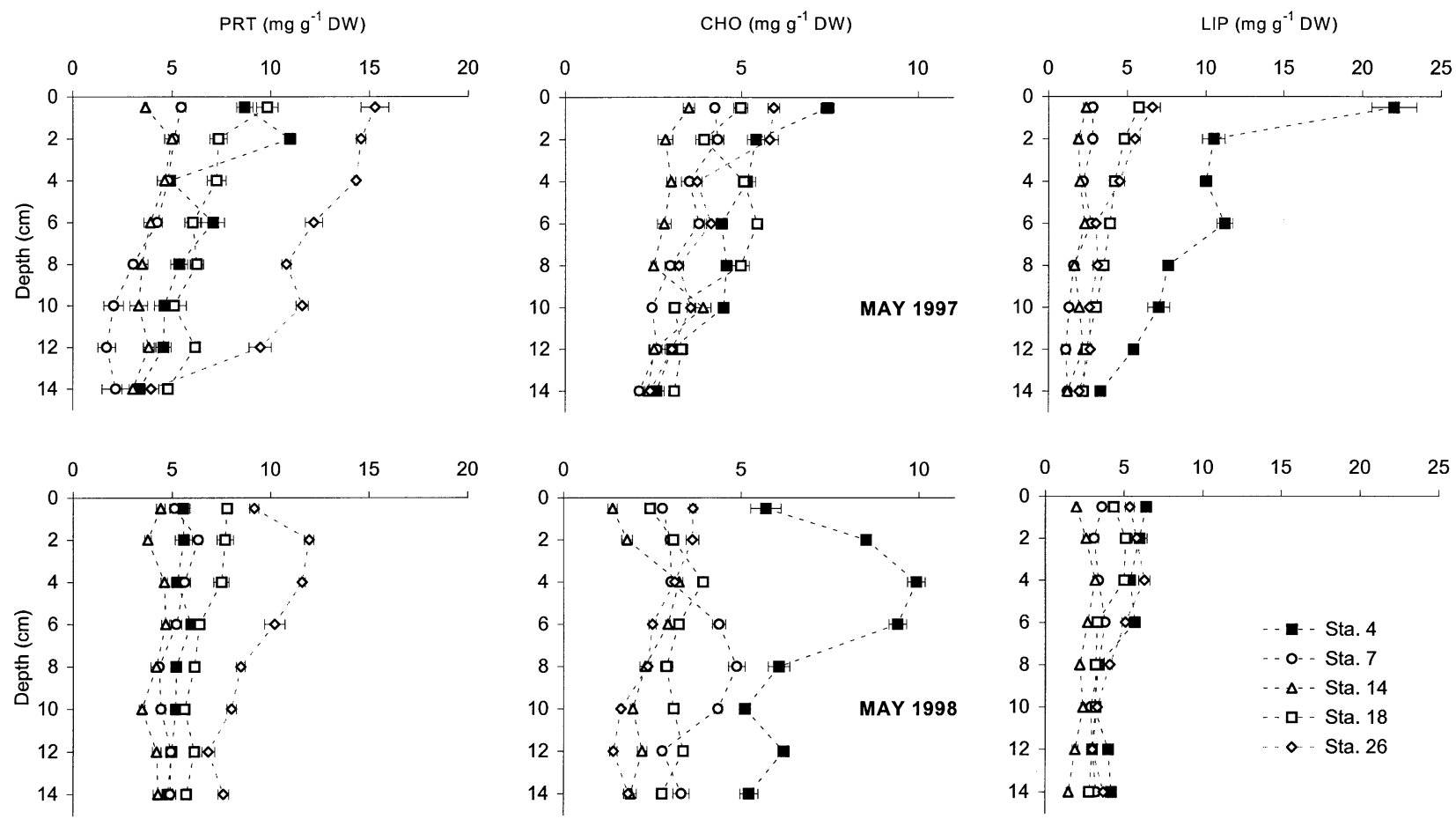

Figure 4. Vertical distribution of the main biochemical components of organic matter at the five sites during May 1997 and May 1998. PRT: proteins; $C H O$ : carbohydrates; LIP: lipids. Values are mean $\pm \mathrm{SE}$.

densities were measured at the outer shelf site. Even though the overall mean abundance of meiofauna showed no significant differences between both 1997 and 1998 (factorial ANOVA $F_{1,20}=3.04, P=0.09$ ), significant differences were found between sites $\left(F_{4,20}=41.73\right.$,
$P<0.01)$. An interaction between sites and sampling dates was detected $\left(F_{4,20}=6.54, P<0.01\right)$, indicating differences between same sites in different periods. In fact, significant increases in meiofaunal abundances (U-test, $P<0.05$ ) from May 1997 to May 1998 were

Table III. Variation of total organic carbon, biochemical components, and organic matter quality in the top $1 \mathrm{~cm}$ sediment layer during May 1997 and May 1998.

\begin{tabular}{|c|c|c|c|c|c|c|c|c|}
\hline Station & TOC & $P R T$ & $L I P$ & $\mathrm{CHO}$ & C-PRT/TOC & C-LIP/TOC & C-CHO/TOC & $C-L O M / T O C$ \\
\hline \multicolumn{9}{|c|}{ May 1997} \\
\hline 4 & 49.9 & 8.6 & 22.0 & 7.4 & 8.5 & 30.9 & 5.9 & 45.3 \\
\hline 7 & 31.9 & 5.5 & 2.8 & 4.2 & 8.4 & 6.2 & 5.3 & 19.9 \\
\hline 14 & 29.9 & 3.7 & 2.4 & 3.5 & 6.0 & 6.6 & 4.7 & 16.3 \\
\hline 18 & 37.6 & 9.8 & 5.7 & 5.0 & 12.8 & 10.7 & 5.3 & 28.9 \\
\hline 26 & 50.0 & 15.3 & 6.6 & 5.9 & 15.0 & 9.2 & 4.7 & 28.9 \\
\hline \multicolumn{9}{|c|}{ May 1998} \\
\hline 4 & 34.6 & 5.5 & 6.4 & 5.7 & 7.9 & 12.9 & 6.6 & 27.4 \\
\hline 7 & 31.5 & 5.1 & 3.6 & 2.8 & 8.0 & 8.0 & 3.5 & 19.5 \\
\hline 14 & 25.3 & 4.4 & 2.0 & 1.4 & 8.6 & 5.5 & 2.2 & 16.2 \\
\hline 18 & 36.1 & 7.8 & 4.3 & 2.4 & 10.6 & 8.4 & 2.7 & 21.6 \\
\hline 26 & 46.9 & 9.2 & 5.4 & 3.6 & 9.6 & 8.0 & 3.1 & 20.8 \\
\hline
\end{tabular}

Total organic carbon $(T O C)$ and biochemical components (proteins, $P R T$; lipids, LIP; carbohydrates, $C H O$ ) are expressed in milligrams per gram of dry weight, and their relative contribution to TOC as a percentage; $C$ - LOM: organic matter quality. 
Figure 5. Mean total (a), nematode (b), copepod + nauplii (c), and polychaete (d) abundance during May 1997 and May 1998.

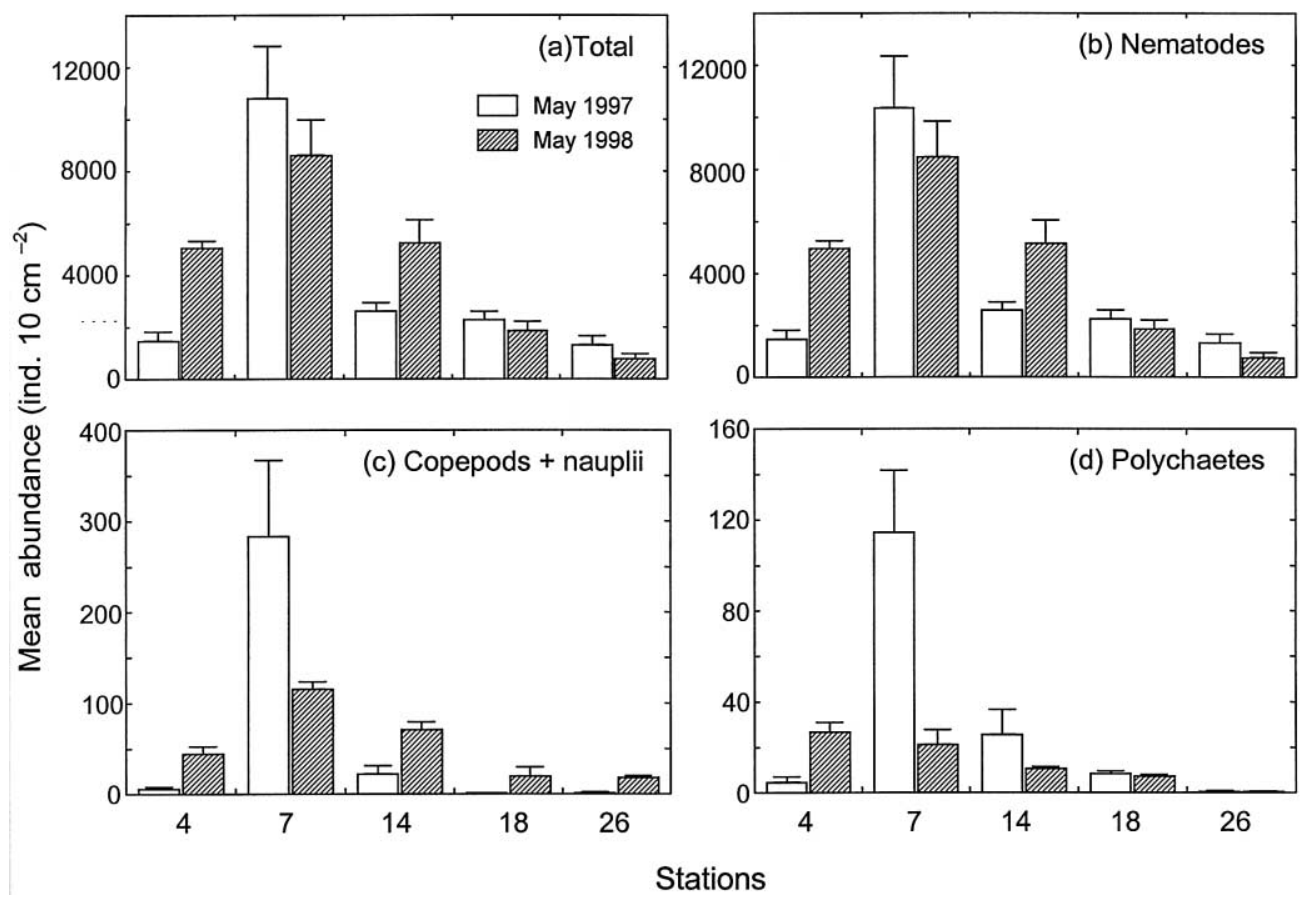

found in the mid-bay and inner shelf sites: from $1474 \pm$ 354 to $5035 \pm 291$ individuals $10 \mathrm{~cm}^{-2}$ and from $2618 \pm 332$ to $5241 \pm 903$ individuals $10 \mathrm{~cm}^{-2}$, respectively (figure 5a). Abundances decreased significantly with water depth from the bay mouth (station7) to the outer shelf (station 26) on both sampling dates (Spearman's $r=-0.97, P<0.01)$. A slight variation in the number of meiofaunal taxa, was observed between the two sampling periods: 13 in May 1997 vs. only 9 in May 1998 (table L W $)$. This reduction was most evident at the inner shelf sites. Nematodes comprised on average more than $98 \%$ of the total metazoan meiofaunal abundance. Nauplii and harpacticoid copepods together accounted for $1.2 \%$, and polychaetes accounted for $0.4 \%$ (table 1 W). Except at the bay mouth station, the relative abundance of copepods and nauplii together increased significantly (figure 5d) from May 1997 to May 1998 (U-test, $P<0.05)$. During this period polychaetes increased only at the mid-bay site; at the outer shelf site polychaete density remained negligible in both periods (Goure $5 d$. The increase of these taxa was restricted to the top $2 \mathrm{~cm}$, where over $90 \%$ of the individuals were found. Patterns of vertical distribution of meiofaunal abundance showed a clear difference between the mid-bay site and the shelf sites (figure 6). At the shelf sites, meiofauna were most abundant within the interval of $2-5 \mathrm{~cm}$ (on average $54 \%$ of the total individuals) declining to $24 \%$ at $5-10 \mathrm{~cm}$ and $2 \%$ at $10-15 \mathrm{~cm}$. In bay sediments, the meiofauna were most abundant in the top $2 \mathrm{~cm}$. In the mid-bay, inner- and middle shelf sites, nematodes penetrated deeper into the sediment during May 1998 (figure 6).

Meiofaunal biomass $(0-15 \mathrm{~cm})$ was dominated by nematodes with about $96 \%$ of the total. A significant biomass increase from May 1997 to May 1998 (U-test, $P<0.05$ ) was found at the mid-bay and inner shelf sites. In the mid-bay, biomass increased from $333.6 \pm 82$ to $1146.0 \pm 61 \mu \mathrm{gC} 10 \mathrm{~cm}^{-2}$ (mean $\pm \mathrm{SE}$ ) and in the inner shelf site, from $615.7 \pm 82$ to $1174 \pm 201 \mu \mathrm{gC} 10 \mathrm{~cm}^{-2}$ (table $1-$. In contrast, the bay mouth, middle shelf and outer shelf sites exhibited a slight decrease in meiofaunal biomass. Following the same trend as observed for abundance, the highest and lowest biomass values were found in the bay mouth and outer shelf sites, respectively. The maximum biomass contribution of taxa other than nematodes was observed at the bay mouth and in the inner shelf sites during May 1997, when polychaetes contributed $5.8 \%$ and $5.4 \%$ of the total biomass, respectively. During May 1998 the biomass contribution of polychaetes to the total decreased to 1.2 and $1.1 \%$ at these stations. Between May 1997 and 1998 there was a noticeable increase in the biomass of polychaetes (from 
Table IV. Total metazoan meiofauna biomass and relative abundance of meiofaunal taxa in the studied sites during May 1997 and May 1998.

\begin{tabular}{|c|c|c|c|c|c|c|c|c|c|c|c|c|c|c|}
\hline Station & Biomass & Nem. & Cop. & Nau. & Pol. & Ost. & Hal. & Gas. & Kin. & Rot. & Tar. & Biv. & Amp. & Cum. \\
\hline \multicolumn{15}{|c|}{ May 1997} \\
\hline 4 & $333.6 \pm 82$ & 99.3 & 0.2 & 0.1 & 0.3 & - & - & - & - & - & - & $*$ & $*$ & - \\
\hline 7 & $2523.9 \pm 419$ & 95.9 & 1.28 & 1.3 & 1.05 & 0.27 & 0.03 & $*$ & $*$ & 0.02 & $*$ & $*$ & - & - \\
\hline 14 & $615.7 \pm 82$ & 98.05 & 0.6 & 0.25 & 0.98 & - & 0.02 & - & - & 0.01 & - & - & 0.06 & - \\
\hline 18 & $512.4 \pm 76$ & 99.6 & & & 0.36 & - & 0.01 & 0.01 & - & - & - & 0.01 & - & - \\
\hline 26 & $294.2 \pm 76$ & 99.3 & 0.05 & 0.06 & 0.05 & - & 0.17 & - & - & 0.09 & 0.07 & - & - & 0.07 \\
\hline \multicolumn{15}{|c|}{ May 1998} \\
\hline 4 & $1146.0 \pm 61$ & 98.5 & 0.3 & 0.6 & 0.5 & $*$ & - & - & - & - & - & - & $*$ & - \\
\hline 7 & $2332.8 \pm 332$ & 98.3 & 0.6 & 0.6 & 0.3 & $*$ & $*$ & - & - & - & - & - & $*$ & - \\
\hline 14 & $1174.6 \pm 201$ & 98.4 & 0.6 & 0.8 & 0.2 & - & - & - & - & - & - & - & - & - \\
\hline 18 & $425.8 \pm 78$ & 98.7 & 0.9 & 0.3 & - & - & - & - & - & - & - & - & - & $*$ \\
\hline 26 & $170.0 \pm 45$ & 97.5 & 1.6 & 0.7 & $*$ & - & - & - & - & - & - & $*$ & - & - \\
\hline
\end{tabular}

Biomass is expressed in micrograms of carbon per $10 \mathrm{~cm}^{-2}$ (mean $\pm \mathrm{SE}$ ), and relative abundance as a percentage of total. Nem.: nematoda, Cop.: copepoda, Nau.: nauplii, Pol.: polychaeta, Ost.: ostracoda, Hal.: halacarida, Gas.: gastrotricha, Kin.: kinorhyncha, Rot.: rotifera, Tar. Tardigrada, Biv.: bivalvia, Amp. amphipoda, Cum.: cumacea, *: present but in percentage less than 0.01 .

4.3 to $28.8 \mu \mathrm{gC} 10 \mathrm{~cm}^{-2}$ ) in the top $2 \mathrm{~cm}$ and of copepods and nauplii (from 1.2 to $7.27 \mu \mathrm{gC} 10 \mathrm{~cm}^{-2}$ ) at the midbay site.

\section{DISCUSSION}

\subsection{Characteristics of the benthic environment}

Sediment TOC values measured in this study were very similar to those determined at the same stations during 1994 (Thamdrup and Canfield. 1996). During May 1997, anoxic conditions prevailed at the sediment-water interface of the mid-bay site, as indicated by low Eh and high levels of sulphide, whereas no anoxic events were detected during the 1998 summer Gutiérrez et al.. 2000)
This explains the higher Eh values and lower sulphide concentrations found in May 1998.

Surface $(0-1 \mathrm{~cm}) C P E$ concentrations were comparable to those found in bathyal sediments off Callao, Peru Neira et al. 2001. In May 1998 a decrease of CPE at all sites in this study, except the outer shelf, was recorded; this decrease was most evident at the mid-bay and middle shelf sites. The Chl $a(0-1 \mathrm{~cm})$ concentrations we measured off Central Chile are similar to those measured in shelf sediments off the Mississippi River (10-80 $\mu \mathrm{g} \mathrm{g}^{-1}$ ) Radziejewska et al. 1996) and higher than those measured at bathyal depths of oxygen minimum zones Levin et al.. 1997: Neira et al.. 2001). The relatively small proportion of $\mathrm{Chl} a$ from the $C P E$ (about $10 \%)$ in Chilean sediments indicates a partial degradation in the water column and/or in the sediment.

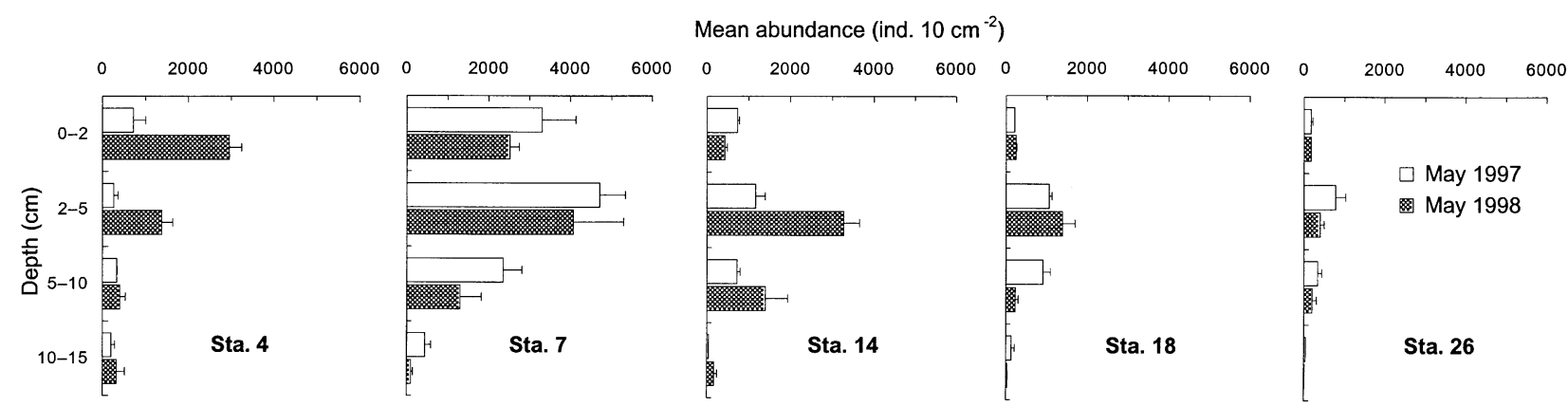

Figure 6. Comparative vertical distribution of mean meiofaunal densities at four sediment levels in the study sites during May 1997 and in May 1998. 
Table V. Concentrations of the three main biochemical components of sediment organic matter reported in the literature for different coastal areas of the world.

\begin{tabular}{|c|c|c|c|c|c|}
\hline Area & Depth (m) & $\begin{array}{l}\text { Lipids } \\
\left(\mathrm{mg} \mathrm{g}^{-1}\right)\end{array}$ & $\begin{array}{l}\text { Proteins } \\
\left(\mathrm{mg} \mathrm{g}^{-1}\right)\end{array}$ & $\begin{array}{l}\text { Carbohydrates } \\
\left(\mathrm{mg} \mathrm{g}^{-1}\right)\end{array}$ & Reference \\
\hline Buzzards Bay, Massachussets & 15 & & $19.9-27.9$ & $10.3-11.1$ & Johnson (1977) \\
\hline Norvegian Sea & & & $0.37-5.81$ & $0.08-0.60$ & Daumas et al. (1978) \\
\hline Balsfjorden, Norway & & 0.13 & & & Sargent et al. (1983) \\
\hline Baltic Sea & 18 & & $3.8-7.7$ & $0.4-4.0$ & Meyer-Reil (1983) \\
\hline Gulf of Gascogne, Atlantic Ocean & 2100 & 0.22 & 1.85 & 2.44 & Khripounoff et al. (1985) \\
\hline W Mediterranean & $10-20$ & $0.01-0.66$ & $0.5-2.6$ & $0.9-4.2$ & Fichez (1991) \\
\hline Ligurian Sea & 10 & $0.06-0.23$ & $0.02-0.04$ & $0.18-0.58$ & Danovaro (1993) \\
\hline E Mediterranean & $100-2400$ & $0.05-0.19$ & $0.07-0.16$ & $1.2-2.4$ & Danovaro et al. (1993)** \\
\hline Prelo, Ligurian Sea & 4 & $0.08-1.07$ & $0.05-1.62$ & $0.28-3.59$ & Danovaro et al. (1994) \\
\hline Tyrrhenian Sea & $20-60$ & $0.003-0.02$ & $0.3-1.7$ & $0.3-1.9$ & Fabiano and Danovaro (1994)* \\
\hline Cretan Sea & $40-1540$ & $0.03-0.69$ & $0.2-3.0$ & $0.25-7.9$ & Tselepides et al. (1996) \\
\hline Marsala lagoon, W Mediterranean & 1 & $0.3-4.5$ & $2.2-12.1$ & $0.8-70.5$ & Pusceddu et al. (1999) \\
\hline Ligurian Sea & $5-135$ & $0.086-0.878$ & $0.012-0.754$ & $0.170-6.610$ & Albertelli et al. (1999) \\
\hline \multicolumn{6}{|l|}{ Central Chile } \\
\hline Bay of Concepcion & 27 & 7.2 & 5.75 & 5.8 & Present study** \\
\hline Continental shelf & $34-120$ & 3.16 & 6.34 & 3.23 & Present study** \\
\hline
\end{tabular}

* Average of 0-10 cm, and ** average of 0-15 cm in this study for May 1997 and May 1998.

\subsection{Elemental and biochemical composition of organic matter}

Differences in the biochemical composition of sedimentary organic matter and hence in the nutritional value were found between years and sites (see figure 4 and table U). In the shelf sites, the $L O M$ was dominated by proteins (on average 48.3\% of total LOM) during 1997 and 1998. However, in May 1997, carbohydrates were the second main component with $30.1 \%$, whereas in May 1998 lipids ranked second (on average 27.4\%). In contrast, at the mid-bay site the relative composition was $47 \%$ lipid, $30.3 \%$ protein, and $22.7 \%$ carbohydrate (May 1997). In May 1998, there was a shift in the sediment composition to $41 \%$ carbohydrate, $31 \%$ protein, and $28 \%$ lipid. The cause of the high concentration of lipid found in the mid-bay site in May 1997 (more than $20 \mathrm{mg} \mathrm{g}^{-1}$ ) remains unknown. Although one possibility involves an anthropogenic source, we believe that it was produced naturally by lipids derived from diatoms like Coscinodiscus Höpner, 1996; Delafontaine and Flemming, 1997) deposited shortly before the sampling. The sediment in the mid-bay in May 1997 was very oily, soupy (fluffy) and smelled of sulphide. This was not the case in May 1998. The change in composition might be due to: 1) the occurrence in May 1998 of a late phase phytoplankton bloom, when highest flux rates of carbohydrate-enriched material usually occur (Danovaro et al. 1999) and/or 2) higher input of terrestrial plant-derived matter during this period. In May 1997 the contribution of fresh phytoplankton and hence of sedimentary nitrogen-rich proteins (Miiller, 1977) and lipids was apparently more important. This idea is supported by the lower $P R T$ : $C H O$ ratio (0.24) in the mid-bay site in May 1998 as compared with May 1997 (0.37). Integrating the first $15 \mathrm{~cm}$ of sediment, we found on average PRT:CHO ratios of 0.36 in May 1997 and of 0.29 in May 1998. These values are higher than the average value of 0.14 reported by Eahiano et_al_(1995) from the Gulf of Marconi (10 m depth, Ligurian Sea), and the value of 0.09 reported by Danovaro et al. (1993) from bathyal sediments of eastern Mediterranean. PRT:CHO ratios off Central Chile are comparable to those reported from the Arno estuary (0.3) Eahiano and Danovare 1994). Table $\mathrm{U}$ summarizes concentrations of the three main biochemical components reported in the literature from sediments in other coastal areas of the world. As expected for a highly productive area dominated by upwelling events, the biopolymeric available fraction of total organic carbon (C-LOM of 37\% in May 1997 and $27 \%$ in May 1998) is greater than in other areas Danovaro et al. 1993: Eabiano and Danovaro. 1994: Eichez. 1991. 


\subsection{Meiofauna response to environmental changes}

Unlike well-oxygenated deep-sea environments, sediments beneath upwelling areas can become oxygen limited. The relatively high percentage of C-LOM of TOC, even at deep sediment layers (table $V d$ ), suggests that food was not a limiting factor for meiofauna. Meiofaunal abundances correlated well with bottom water dissolved oxygen in May 1997 (Spearman's $r=0.89, P=0.03$ ) (figure $7 b$ ), but not with the organic carbon quality indicators (foure 7a). In May 1998, meiofaunal density was more related to organic matter quality (Spearman's $r=0.89, P=0.04)$ than to bottom water dissolved oxygen (Goure $7 b$ ). This suggests a change in importance of both organic matter quality and bottom water dissolved oxygen as limiting factors for the meiofauna, between May 1997 and May 1998. The increased density of copepods and polychaetes (figures $5 c, d$ ) and the penetration of nematodes into the deeper sediment layers during May 1998 (figure 6 ), particularly at the mid-bay site, may be a response to increased bottom water oxygen availability and decreased organic matter quality. Gutiérrez ed al. (2000) observed a similar result at the same stations off Concepción for penetration of bioturbating macrofauna. Higher levels of bottom water dissolved oxygen and a lower organic matter quality in surface sediments appeared to provide better conditions for bioturbators.

\subsection{El Niño effect on meiofauna-Thioploca relationships}

A Thioploca biomass up to $1 \mathrm{~kg} \mathrm{~m}^{-2}$ (wet weight, including sheaths), were recorded during summer 1975 and 1994 Gossing et al 1995; Gallardo, 1977; Hettel et al 1996). However, from summer 1996-1997 a notable decrease has been observed down to $<100 \mathrm{~g} \mathrm{~m}^{-2}$ Schul etal.,1996: Schulzet al, 2000). During the present study, Thioploca biomass was one to two orders of magnitude lower than in 1996. In May 1997 meiofauna in the uppermost $15 \mathrm{~cm}$ of sediment contributed a small percentage to the carbon pool, on average $0.84 \%$ with $0.856 \mathrm{gC} \mathrm{m}^{-2}$, while Thioploca contributed $0.95 \%$ with $0.966 \mathrm{gC} \mathrm{m}^{-2}$. In May 1998 the contribution of meiofauna and Thioploca to the carbon pool was $1.39 \%$ $\left(0.972 \mathrm{gC} \mathrm{m}^{-2}\right)$ and $0.2 \%\left(0.14 \mathrm{gC} \mathrm{m}^{-2}\right)$, respectively. Macrofauna contributed on average over $98 \%$ of the biomass with $99.6 \mathrm{gC} \mathrm{m}^{-2}$ in May 1997 and
$68.71 \mathrm{gC} \mathrm{m}^{-2}$ in May 1998. There was a reduction in meiofaunal density at the bay mouth, middle shelf, and outer shelf sites in May 1998, whereas an increase was observed at the mid-bay and inner shelf sites. The most likely explanation for this increase in density is the increase of bottom water dissolved oxygen during summer 1997-1998 Gutiérrez et al, 2000). Since May 1997, higher levels of bottom water dissolved oxygen have been recorded, particularly over the shallower stations. From the 1996-1997 spring to early fall, values of bottom water dissolved oxygen ranged between 0 and $0.5 \mathrm{~mL} \mathrm{~L}^{-1}$, while in the 1997-1998 period, oxygen values were always above $1 \mathrm{~mL} \mathrm{~L}^{-1}$. Changes in community structure were observed by Tarazona (1988) and Tarazona et al. (1996) in the Ancón Bay (Peru), and were attributed to oxygen pulses that maintained the average value above the normal mean (Arntz et_al, 1991). This seems to be the case of the mid-bay site, where a significant meiofaunal increase occurred. Also, in the mid-bay a significant decrease of sulphide was recorded in the sediment (U-test $P<0.05$; table -1 ). At the inner shelf site, a decrease of meiofaunal biomass was observed in the top $2 \mathrm{~cm}$, but an increase occurred in the deeper layers. Concurrently, higher sulphide concentrations were found. These conditions favoured those nematodes better adapted to reduced conditions Greiser and Eaubel, 1988: Meyers et al. 1988: Powell, 1989): hence they could concentrate deeper along the redox discontinuity layer, where the bacterial activity is high $\amalg \propto r-$ gensen. 1977. Another change attributed to the El Niño in Central Chile was a severe reduction of the primary production, from values usually between 1.5 and $5 \mathrm{gC} \mathrm{m}^{-2}$ day $^{-1}$ in non-El Niño conditions, to less than $0.17 \mathrm{gC} \mathrm{m}^{-2}$ day $^{-1}$ (Farias and Ulloa, personnal communication).

A positive correlation between Thioploca and meiofaunal biomass was observed at all stations in May 1997 (Pearson's $r=0.79, P<0.01$; figure 8). However, no correlation was found in May 1998 when Thioploca biomass was low. This evidence by itself does not allow us to validate the role of Thioploca in detoxifying sediments because both Thioploca and meiofauna could be responding to the same factors. However, the positive correlation of Thioploca biomass with the meiofauna might suggest that at least in May 1997, during non-El Niño conditions, Thioploca presence could have had a positive influence on the meiofauna. 
Table VI. Vertical profiles of chloroplastic pigment equivalents, labile organic matter, organic matter quality, and meiofaunal abundances within the sediment, during May 1997 and May 1998.

\begin{tabular}{|c|c|c|c|c|c|c|c|c|c|c|c|c|c|c|c|}
\hline \multirow[b]{2}{*}{ Depth $(\mathrm{cm})$} & \multicolumn{3}{|c|}{ Station 4} & \multicolumn{3}{|c|}{ Station 7} & \multicolumn{3}{|c|}{ Station 14} & \multicolumn{3}{|c|}{ Station 18} & \multicolumn{3}{|c|}{ Station 26} \\
\hline & $C P E$ & $L O M$ & $C-L O M / T O C$ & $C P E$ & $L O M$ & C-LOM/TOC & $C P E$ & $L O M$ & $C-L O M / T O C$ & $C P E$ & $L O M$ & C-LOM/TOC & $C P E$ & $L O M$ & C-LOM/TOC \\
\hline \multicolumn{16}{|l|}{ May 1997} \\
\hline $0-2$ & 154.6 & 38.1 & 45.3 & 60.6 & 12.5 & 19.9 & 52.1 & 9.6 & 43.5 & 151.2 & 20.6 & 28.8 & 151.2 & 27.8 & 29.0 \\
\hline $2-5$ & 68.5 & 23.5 & 30.4 & 28.8 & 11.3 & 18.5 & 27.4 & 9.7 & 44.2 & 47.5 & 16.3 & 25.7 & 47.5 & 24.2 & 26.6 \\
\hline $5-10$ & 28.2 & 18.8 & 34.4 & 18.1 & 8.1 & 20.5 & 22.4 & 8.6 & 40.7 & 41.6 & 13.8 & 24.5 & 41.7 & 18.1 & 25.0 \\
\hline $10-15$ & 17.2 & 11.1 & 23.4 & 8.0 & 5.5 & 18.7 & 20.5 & 7.6 & 37.1 & 26.9 & 11.0 & 23.9 & 26.9 & 11.7 & 31.3 \\
\hline \multicolumn{16}{|l|}{ May 1998} \\
\hline $0-2$ & 70.2 & 17.6 & 27.4 & 44.7 & 11.5 & 19.5 & 33.3 & 7.8 & 16.2 & 74.3 & 14.5 & 21.7 & 70.9 & 18.2 & 20.7 \\
\hline $2-5$ & 39.2 & 20.3 & 31.0 & 34.7 & 12.3 & 19.9 & 28.5 & 9.6 & 20.3 & 57.7 & 16.1 & 24.9 & 51.6 & 21.2 & 24.4 \\
\hline $5-10$ & 35.7 & 16.3 & 27.0 & 32.1 & 12.6 & 21.3 & 25.1 & 8.9 & 21.5 & 37.1 & 12.4 & 21.8 & 42.5 & 15.2 & 19.8 \\
\hline $10-15$ & 28.3 & 14.7 & 23.1 & 20.1 & 11.1 & 21.9 & 19.5 & 7.9 & 17.8 & 34.2 & 11.9 & 22.1 & 43.4 & 12,1 & 21.5 \\
\hline
\end{tabular}

$T O C$, total organic carbon; $C P E$, chloroplastic pigment equivalents (in micrograms per gram); $L O M$, labile organic matter, sum of lipids, proteins and carbohydrates (in milligrams per gram of dry weight); $C$-LOM/TOC, organic matter quality (in percent), $C$ - $L O M$ is $L O M$ in terms of carbon equivalents. 


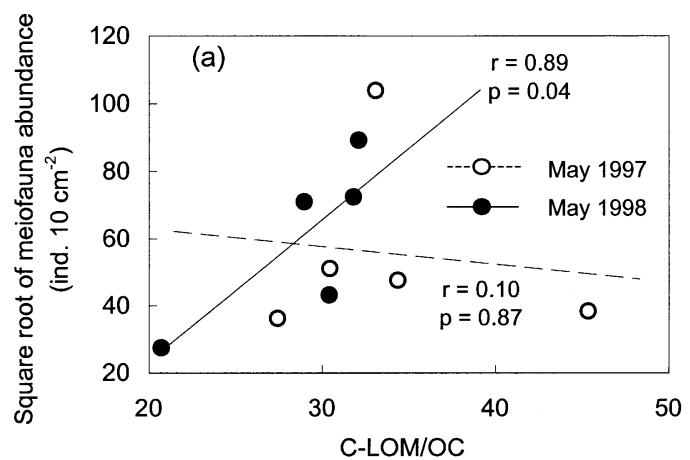

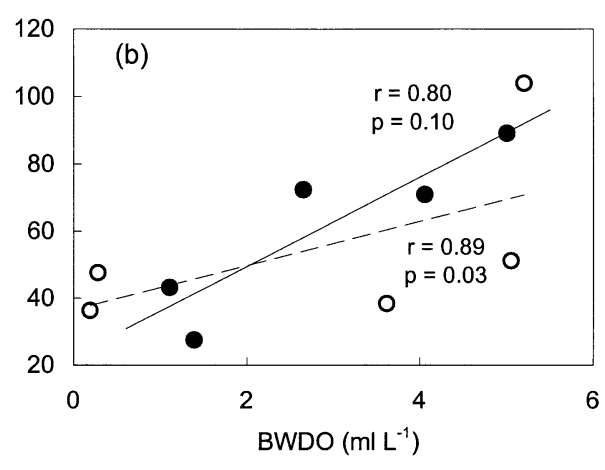

Figure 7. Relationship between meiofaunal abundance and organic matter quality $(C-L O M / O C)(a)$ and bottom water dissolved oxygen $(B W D O)$ (b), in May 1997 and in May 1998. Spearman rank correlation's $r$ and significance level are indicated $(n=5)$.
We conclude that the 1997-1998 El Niño caused changes in meiofauna community structure as a direct result of the alteration of hydrographic conditions and biogeochemical regime. There was reduced primary production, substantially lower than previously reported for the area, an increase in bottom water dissolved oxygen, and a decrease of the biopolymeric fraction relative to total organic carbon, hence a reduction of organic matter quality. Major faunal changes occurred at the mid-bay and inner shelf sites, where significant meiofaunal density increases occurred. Consistent with the higher bottom water oxygen levels caused by El Niño, harpacticoid densities increased at all sites except at the bay mouth in May 1998.

A relatively high fraction of organic matter deposited onto the sediments was labile and hence of potentially high nutritional value for benthic consumers. Despite its

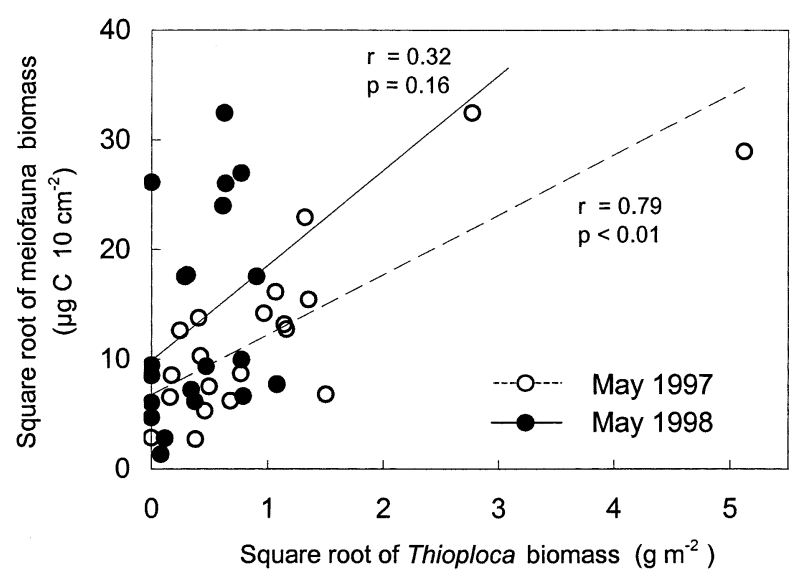

Figure 8. Relationship between Thioploca and meiofaunal biomass at the study sites, during May 1997 and May 1998. Pearson product-moment correlation's $r$ and significance level are indicated $(n=20)$. slight decrease at the end of the El Niño event (from 37\% to $27 \%$ ), organic matter likely never represented a limiting factor for the meiofauna.

The authors would like to thank Dr. Thomas Höpner for providing laboratory facilities and support. Thanks are also due to Dr. Lisa Levin, Dr. Roberto Danovaro, and an anonymous reviewer for valuable suggestions and critical comments. We are grateful to Michael Rackemann and Silke Schier for technical assistance in the lab. This work was supported by grants from the Chilean National Fund for Scientific and Technological Research, and the FONDAP-Humboldt Program. Additional support to C.N. was provided by the ICBM and to J.S. and D.G. by the Deutscher Akademischer Austauschdienst.

\section{REFERENCES}

Ahumada, R., Rudolph, A., Martínez, V., 1983. Circulation and fertility of water in Concepcion Bay, Chile. Estuar. Coast. Shelf Sci. 16, 95-105.

Albertelli, G., Covazzi-Harriague, A., Danovaro, R., Fabiano, M., Fraschetti, S., Pusceddu, A., 1999. Differential responses of bacteria, meiofauna and macrofauna in a shelf area (Ligurian Sea, NW Mediterranean): role of food availability. J. Sea Res. 42, 11-26.

Andrassy, I., 1956. Die Rauminhalts- und Gewichtsbestimmung der Fadenwürmer (Nematoden). Acta Zool. Acad. Scientiarum Hungaricae 2, 1-15.

Arntz, W.E., Tarazona, J., Gallardo, V.A., Flores, L.A., Salzwedel, H., 1991. Benthos communities in oxygen-deficient shelf and upper slope areas of the Peruvian and Chilean Pacific coast, and changes caused by El Niño. In: Tyson, R.V., Pearson, T.H. (Eds.), Modern and ancient continental shelf anoxia. Geol. Soc. Spec. Publ. 58, pp. 131-154.

Barnett, P.R., Watson, J., Connelly, D., 1984. A multiple corer for taking virtually undisturbed samples from shelf, bathyal and abyssal sediments. Oceanol. Acta 7, 399-408. 
Bernal, P.A., Ahumada, R., González, H., Pantoja, S., Troncoso, A., 1989. Flujo de carbono en un modelo trófico pelágico para Bahía de Concepción, Chile. Biol. Pesq. 18, 5-14.

Boetius, A., Scheibe, S., Tselepides, A., Thiel, H., 1996. Microbial biomass and activities in deep-sea sediments of the Eastern Mediterranean: trenches are benthic spots. Deep-Sea Res. 43, 1439-1460.

Cline, J.D., 1969. Spectrophotometric determination of hydrogen sulfide in natural waters. Limnol. Oceanogr. 14, 454-458.

Danovaro, R., 1993. Analisi della dinamica e della struttura trofica di comunità meiobentioniche in relazione al contenuto ed alla composizione della sostanza organica particella (Mar Ligure), Ph.D. Thesis. University of Pisa, Pisa.

Danovaro, R., Fabiano, M., Boyer, M., 1994. Seasonal changes of benthic bacteria in a seagrass bed (Posidonia oceanica) of the Ligurian Sea in relation to origin, composition, and fate of the sediment organic matter. Mar. Biol. 119, 483-500.

Danovaro, R., Fabiano, M., Della Croce, N., 1993. Labile organic matter and microbial biomass in deep-sea sediments (Eastern Mediterranean Sea). Deep-Sea Res. 40, 953-965.

Danovaro, R., Pusceddu, A., Mirto, S., Fabiano, M., 1999. Meiofaunal assemblages associated to scallop beds (Adamussium colbecki) in the coastal sediments of Terra Nova Bay (Ross Sea, Antarctica). Antarct. Sci. 11, 415-418.

Daumas, R.A., Laborde, P., Paul, R., Romano, J.C., Sautriot, D., 1978. Les mécanismes de transformation de la matière organique en Atlantique intertropical. Étude de la minéralisation et de la diagénèse dans les sédiments superficiels. In: Combaz, A., Pelet, R. (Eds.), Géochimie organique des sédiments marins profonds, Orgon II.. CNRS, Paris.

Delafontaine, M.T., Flemming, B.W., 1997. Large-scale sedimentary anoxia and faunal mortality in the German Wadden sea (Southern North Sea) in June 1996: a man-made catastrophe or a natural black tide. Dt. Hydrogr. Zeitschr. (Suppl. 7), 21-27.

Fabiano, M., Danovaro, R., 1994. Composition of organic matter in sediments facing a river estuary (Tyrrhenian Sea): relationships with bacteria and microphytobenthic biomass. Hydrobiol. 277, 71-84.

Fabiano, M., Danovaro, R., Fraschetti, S., 1995. A three-year time series of elemental and biochemical composition of organic matter in subtidal sandy sediments of the Ligurian Sea (northwestern Mediterranean). Cont. Shelf Res. 15, 1453-1469.

Fabiano, M., Povero, P., Danovaro, R., 1993. Distribution and composition of particulate organic matter in Ross Sea (Antarctica). Polar Biol. 13, 525-533.

Feller, R.J., Warwick, R.M., 1988. Energetics. In: Higgins, R.P., Thiel, H. (Eds.), Introduction to the study of meiofauna. Smithsonian Institution Press, Washington, D.C., pp. 181-196.

Ferdelman, T.G., Lee, C., Pantoja, S., Harder, J., Bebout, B.M., Fossing, H., 1997. Sulfate reduction and methanogenesis in a Thioploca-dominated sediment off the coast of Chile. Geochim. Cosmochim. Acta 61, 3065-3079.

Fichez, R., 1991. Composition and fate of organic matter in submarine cave sediments: implications for the biogeochemical cycle of organic carbon. Oceanol. Acta. 14, 369-377.

Fossing, H., Gallardo, V.A., Jørgensen, B.B., Hüttel, M., Nielsen, L.P., Schulz, H., Canfield, D.E., Forster, S., Glud, R.N., Gundersen, J.K.,
Küver, J., Ramsing, N.B., Teske, A., Thamdrup, B., Ulloa, O., 1995. Concentration and transport of nitrate by the mat-forming sulphur bacterium Thioploca. Nature 374, 713-715.

Gallardo, V.A., 1977. Large benthic microbial communities in sulfide biota under Peru-Chile subsurface countercurrent. Nature 268, 331-332.

Gallardo, V.A., 1985. Efectos del fenómeno de El Niño sobre el bentos sublitoral frente a Concepción, Chile, Arntz, W., Landa, A., Tarazona, J. (Eds.). El Niño y su impacto en la fauna marina. Inst. Mar Perú (Callao) Inf. 198, 79-85.

Gallardo, V.A., Carrasco, F.D., Roa, R., Cañete, J.I., 1995. Ecological patterns in the benthic macrobiota across the continental shelf off Central Chile. Ophelia 40, 167-188.

Gallardo, V.A., Carrasco, F.D., Roa, R., Quiñones, R., Ulloa, O., Cañete, J.I., Mesías, J., Sobarzo, M., Pineda, V., Baltazar, M., 1996a. Benthic habitat detoxification by a bacterial biomat (Thioploca spp.)? Observations on the recruitment of the squat lobster (Pleuroncodes monodon) off Central Chile, Ninth southern African marine science symposium, Marine science in southern Africa, past perspectives and future challenges. University of Cape Town, Cape Town, p. 65.

Gallardo, V.A., Roa, R., Carrasco, F.D., Cañete, J.I., Enríquez-Briones, S., Baltazar, M., 1996b. Bathymetric and seasonal patterns in the sublittoral megafauna off Central Chile. J. Mar. Biol. Ass. UK. 76, 311-326.

Giere, O., 1993. Meiobenthology. The microscopic fauna in aquatic sediments. Springer-Verlag, Berlin.

Greiser, N., Faubel, A., 1988. Biotic factors. In: Higgins, R.P., Thiel, H. (Eds.), Introduction to the study of meiofauna. Smithsonian Institution Press, Washington, D.C., pp. 79-114.

Gutiérrez, D., Gallardo, V.A., Mayor, S., Neira, C., Vásquez, C., Sellanes, J., Rivas, M., Soto, A., Baltazar, M., 2000. Effects of dissolved oxygen and fresh organic matter on the bioturbation potential of macrofauna in sublittoral sediments off Central Chile during the 1997/98 El Niño. Mar. Ecol. Prog. Ser. 202, 81-99.

Henrichs, S.M., Farrington, J.W., 1984. Peru upwelling region sediments near $15^{\circ} \mathrm{S} .1$. Remineralization and accumulation of organic matter. Limnol. Oceanogr. 29, 1-19.

Höpner, T., 1996. Schwarze Tage im Nationalpark Wattenmeer. Spektrum der Wissenschaft 8/96, pp. 16-21.

Huettel, M., Forster, S., Klöser, S., Fossing, H., 1996. Vertical migration in the sediment-dwelling sulfur bacteria Thioploca spp. in overcoming diffusion limitations. Appl. Environ. Microbiol. 62, $1863-1872$.

Jensen, P., 1984. Measuring carbon content in nematodes. Helgol. Meeresunters. 38, 83-86.

Johnson, R.G., 1977. Vertical variation in particulate organic matter in the upper twenty centimeters of marine sediments. J. Mar. Res. 35, 272-282.

Jørgensen, B.B., 1977. Bacterial sulfate reduction within reduced microniches of oxidized marine sediments. Mar. Biol. 41, 7-17.

Khripounoff, A., Crassous, P., Desbruyères, D., Le Cox, J.R., 1985. Le flux organic particulaire et ses transformations à l'interface 
eau-sédiment. In: Laubier, L., Monniot, C. (Eds.), Peuplements profonds du golfe de Gascogne. Ifremer publications, Brest, pp. 101-118.

Levin, L.A., Gage, J., Lamont, P., Cammidge, L., Patience, A., Martin, C., 1997. Infaunal community structure in a low oxygen, organicrich habitat on the Oman margin. In: Hawkins, L., Hutchinson, S., Jenson, A., Williams, J., Sheader, M. (Eds.), Responses of marine organisms to their environment. Thirtieth European Marine Biology Symposium. Southampton Oceanography Centre, Southampton, pp. 223-230.

McPhaden, M.J., 1999. Genesis and evolution of the-98 El Niño. Science 283, 950-954.

Meyer-Reil, L.A., 1983. Benthic response to sedimentation events during autumn to spring at a shallow water station in the Western Kiel Bight. II Analysis of bacterial populations. Mar. Biol. 77, 247-256.

Meyers, M.B., Powell, E.N., Fossing, H., 1988. Movement of oxibiotic and thiobiotic meiofauna in response to changes in pore water-water oxygen and sulfide gradients around macro-infaunal tubes. Mar. Biol. 98, 395-414.

Müller, P.J., 1977. C:N ratios in Pacific deep-sea sediments: effects of inorganic ammonium and organic nitrogen compounds sorbed by clays. Geochim. Comochim. Acta. 41, 765-776.

Neira, C., Rackemann, M., 1996. Black spots produced by buried macroalgae in intertidal sandy sediments of the Wadden Sea: effects on the meiobenthos. J. Sea Res. 36, 153-170.

Neira, C., Sellanes, J., Levin, L.A., Arntz, W.E., 2001. Meiofaunal distributions on the Peru margin: relationship to oxygen and organic matter availability Deep-Sea Res. 48 (in press).

Pfannkuche, O., 1985. The deep-sea meiofauna of the Porcupine Seabight and abyssal plain (NE Atlantic): population structure, distribution, standing stocks. Oceanol. Acta 8, 343-348.

Powell, E.N., 1989. Oxygen, sulfide and diffusion: why thiobiotic meiofauna must be sulfide-insensitive first-order respirers. J. Mar. Res. 47, 887-932.

Pusceddu, A., Sarà, G., Armeni, M., Fabiano, M., Mazzola, A., 1999. Seasonal and spatial changes in the sediment organic matter of a semi-enclosed marine system (W Mediterranean Sea). Hydrobiol. 397, 59-70.

Radziejewska, T., Fleeger, J.W., Rabalais, N., Carman, K.R., 1996. Meiofauna and sediment chloroplastic pigments on the continental shelf off Louisiana, USA. Continent. Shelf Res. 16, 1699-1723.
Sargent, J.R., Hopkins, C.C.E., Siering, J.V., Youngson, A., 1983. Partial characterization of organic material in surface sediments from Balsfjorden, Northern Norway, in relation to its origin and nutritional value for sediment-ingesting animals. Mar. Biol. 76, 87-94.

Schulz, H.N., Jørgensen, B.B., Fossing, H.A., Ramsing, N.B., 1996. Community structure of filamentous, sheath-building sulfur bacteria, Thioploca spp., off the coast of Chile. Appl. Environ. Microbiol. 62, 1855-1862.

Schulz, H.N., Strotmann, B., Gallardo, V.A., Jørgensen, B.B., 2000. Population study of the filamentous sulfur bacteria Thioploca spp. off the bay of Concepción. Mar. Ecol. Prog. Ser. 200, 117-126.

Stal, L.J., Van Gamerden, H., Krumbein, W.E., 1984. The simultaneous assay of chlorophyll and bacteriochlorophyll in natural microbial communities. J. microbiol. Meth. 2, 295-306.

Tarazona, J., 1988. Positive effects of 'El Niño' on macrozoobenthos inhabiting hypoxic areas of the Peruvian upwelling system. Oecologia 76, 184-190.

Tarazona, J., Arntz, W.E., Canahuire, E., 1996. Impact of two 'El Niño' events of different intensity on the hypoxic soft bottom macrobenthos off the central Peruvian coast. Mar. Ecol. 17, 425-446.

Taylor, I.S., Paterson, D.M., 1998. Microspatial variation in carbohydrate concentrations with depth in the upper millimetres of intertidal cohesive sediments. Estuar. Coast. Shelf. Sci. 46, 359-370.

Thamdrup, B., Canfield, D.E., 1996. Pathways of carbon oxidation in continental margin sediments off Central Chile. Limnol. Oceanogr. 41, 1629-1650.

Tselepides, A., Danovaro, R., Della Croce, N., Duineveld, G., Polychronaki, T., Dell'Anno, A., Dafnomili, E., Plaiti, W., Akumianaki, G., Martorano, D., 1996. Seasonnal variability of chloroplastic pigment, TOC, TON; ATP and labile organic matter (carbohydrates, lipids, proteins and nucleic acids) over the continental margin and deep-sea sediments of the oligotrophic Cretan Sea. In: Tselepides, A., Papadopoulou, K.N., Polychronaki, T. (Eds.), CINCS: Pelagic-benthic coupling in the oligotrophic Cretan Sea. MAST II, Mediterranean targeted project final report. MAST, Heraklion, pp. 113-134.

Wieser, W., 1960. Benthic studies in Buzzards Bay. II. The meiofauna. Limnol. Oceanogr. 5, 121-137.

Wilkinson, L., Hill, M., Welna, J.P., Birkenbeuel, G.K., 1992. Systat for Windows: Statistics, Version 5. Systat, Inc., Evanston, IL. 